\title{
The Impact of Food Manufacturing Practices on Food borne Diseases
}

\author{
Cristina Paiva de Sousa* \\ Universidade Federal de São Carlos; Rodovia Washington Luis, Km 235; 13565-905; São Carlos - SP - Brasil
}

\begin{abstract}
Food-borne illness is a major international problem and an important cause of reduced economic growth. The contamination of the food supply with the pathogens and its persistence, growth, multiplication and/or toxin production has emerged as an important public health concern. Most of these problems could be controlled with the efforts on the part of the food handlers, whether in a processing plant, a restaurant, and others. In contrast with most chemical hazardous compounds, the concentration of food pathogens changes during the processing, storage, and meal preparation, making it difficult to estimate the number of the microorganisms or the concentration of their toxins at the time of ingestion by the consumer. This review shows main microorganisms related to the manipulation practices such as Staphylococcus spp., Escherichia coli and Salmonella spp. and describes the factors regarding the food-borne illness highlighting the impact of good manipulation practices on the food safety and food quality.
\end{abstract}

Key words: food-borne diseases, Staphylococcus spp., Escherichia coli, Salmonella spp., food handlers

\section{INTRODUCTION}

As urbanization increases worldwide, eating meals outside the home is becoming more frequent. Despite the growth of this sector, there is no effective education or training of the food handlers or hygienic control of the food sold on the streets. The contamination of the food supply with pathogens and its persistence, growth, multiplication and/or toxin production has emerged as an important public health concern. Food-borne illness is a major international problem and an important cause of the reduced economic growth. Over two hundred different diseases are known to be transmitted by the food (Bryan, 1982). Despite this, only a fraction of all food-borne infections are ever diagnosed and officially reported, or can be traced to a definite vehicle and a specific causative agent (Lukinmaa et al., 2004). In this context, the manipulation practices represent an important factor.

The problems of the food safety in the industrialized world differ considerably from those faced by the developing countries. The traditional methods are used for marketing the fresh produce in the latter countries, there are norms to the food processing and packaging in the industrialized countries. In the developing countries, like Brazil, a large proportion of the ready-to-eat food is sold on the streets. These practices can contribute to enhance the biological, chemical and physical hazards regarding the food safety and microbiological food quality.

The purpose of this review was to trace the factors regarding the food-borne illness highlighting the

* Author for correspondence 
impact of the good manipulation practices on the food safety and food quality.

\section{Street food concept}

The term "street food" could be defined as a variety of ready-to-eat foods and beverages sold, and sometimes prepared in public places. As with the fast food, the final preparation occurs when the meals are ordered by the customers. The street food may be consumed at the same place or can be taken away and consumed elsewhere. The people who depend on such food are often more interested in its convenience than in questions of its safety, quality and hygienic aspects of the consumed food. The hygienic aspects of the vending operations are of interest of the public health, such as the hand washing practices as well as the utensils and dishes that are often washed on the bowls. Disinfection is not usually carried out and the vectors (insects, rodents) may be present in the food manipulation place. Food is not always adequately protected from these vectors and refrigeration practices are not usually available (Mensah et al., 2002). From the point of view of their effect on the burden of the disease, the main health benefit of the water supply, sanitation, and hygiene is a reduction in the diarrheal disease, although the effects on other diseases are substantial.

The epidemiological data indicate that the crosscontamination during the food preparation contributes notably to the occurrence of the foodborne diseases (Forsythe and Hayes, 1988). To ensure that the food is microbiologically safe, both the manipulators (WHO, 2002) and the food need to be continually monitored (Gilling et al., 2001). The commercial manufacture of the food sold on the streets consists of a small number of the operations, but this critical process can lead to the introduction of the microorganisms or the proliferation of those already present. Possible sources of the microbial contamination have been identified as i) unhygienic handling; ii) raw material; iii) inadequate cleaning of the machines used to cut the food, knives, contact surfaces, clothes and manipulators hands, and iv) airborne contamination.

\section{Main microorganisms related to manipulation practices}

The hygienic standard of food can be assessed by the analysis of the indicator microorganisms (Forsythe and Hayes, 1988). Besides this, there are major microorganisms groups that are used alone or together in order to verify the microbiological characteristics and the hygienic condition of the food.

\section{Coliforms}

The fecal coliforms, e.g., Escherichia coli, are presently used as an indicator of the sanitary conditions. Since this microorganism is a typical component of the fecal microbiota, its detection may indicate the potential occurrence of other microorganisms which could be even more pathogenic to the man and both domestic and wild animals. It includes a broad variety of strains types, ranging from the highly pathogenic strains causing the worldwide outbreaks of severe disease to avirulent isolates which are part of the normal intestinal microbiota, or which are well characterized and safe laboratory strains. The species includes the intestinal diarrheagenic E. coli and extraintestinal pathogens (Sousa, 2005; Sousa, 2003; Souza, 2005). Several E. coli pathotypes have been implicated with the diarrhoeal illness, a major public health problem worldwide, with over two million deaths occurring each year (WHO, 2002).

Due to the ease of the access of the pathogens ingested with the food, the human gastro-intestinal tract is susceptible to the diarrhoeagenic E. coli infections. E. coli originally of interest as an indicator of the fecal contamination, could be a collection of the strains, some of which are pathogenic, like enterohaemorragic $E$. coli (EHEC). The enterohaemorragic E. coli strains are implicated in the food-borne diseases principally due to the ingestion of the uncooked minced meat and raw milk (Sousa, 2005). These strains produce shiga-like toxin 1 (stx1), shiga-like toxin 2 (stx2) and variants thereof (Ménard and Dubreuil, 2002). They are involved in the episodes of diarrhea with complications. This pathogen gained attention in 1993 when a massive outbreak in the western United States of America was linked to the contaminated hamburger patties (Lamps, 2007).

The serotype O157:H7 is the prototype of increasing importance and is associated with the hemorrhagic colitis, bloody diarrhea and the hemolytic uremic syndrome (HUS). The EHEC typically cause an afebrile bloody colitis and, in about $10 \%$ of patients, this infection can be followed by the HUS (Pickering et al., 1994). Like the EPEC (enteropathogenic E. coli), the EHEC elicit an attaching and effacing lesion of the 
intestinal mucosa, a phenotype that requires a functional eaeA chromosomal gene. The elaboration of an oligomeric shiga-like toxin (SLT-I or SLT-II) contributes to the hemorrhagic colitis and the development of the systemic sequelae of disease. The EHEC adhere to the mucosa by virtue of a plasmid-borne fimbrial antigen that is distinct from the BFP (bundle forming pili) and the plasmid itself is conserved among the EHEC strains as is the EAF ( EPEC adherence factor) plasmid among EPEC.

The presence of the marker groups such as coliforms and E. coli in the processed products demonstrates possible process related to the contamination (Blood and Curtis, 1995) and indicates poor manufacturing practices and inadequate factory hygiene standards. The presence of $E$. coli and other coliform bacteria (e.g. enterococci) is generally an indication of fecal contamination of the water and food. The quantification of the total number of $E$. coli present is, therefore, an integral part of the quality assessment of food and water.

\section{Staphylococcus species}

Staphylococcus aureus is a major human pathogen capable of causing a wide range of infections. Staphylococcal food poisoning caused by the enterotoxigenic producing $S$. aureus is an important foodborne disease throughout the world. Many staphylococcal strains produce enterotoxin, the cause of the staphylococcal food poisoning. If a strain is enterotoxigenic, it is possible for it to be involved in the food poisoning (Bergdoll, 2000). Globally, the staphylococcal intoxication remains a very common food poisoning. The high prevalence of the staphylococci in raw foods of animal origin requires effective processing for safety. The human beings are a major reservoir for the post-process recontamination. There are relations among the taxonomic aspects, ecosystem and the virulence factors related to Staphylococcus and its importance in the food and public health (Bergdoll, 2000).

Carmo et al. (2004) reported one outbreak within hours of the food consumption where 4000 patients experienced acute gastroenteritis and approximately $2000 \quad(50 \%)$ overwhelmed the emergency departments of 26 hospitals in Brazil. Approximately $20 \%$ required subsequent admission, and of these patients, 81 (approximately 20\%) were admitted to the intensive care units. A total of 16 (approximately
$20 \%$ of those admitted to the intensive care unit) patients developed irreversible multi-system shock and expired. The trace-back investigation implicated the food manipulators which were culture positive for the enterotoxigenic $S$. aureus as the source of the contamination. These data provides information on the magnitude and severity of oral exposure to staphylococcal enterotoxin.

The effect of the intrinsic characteristics of the foods $(\mathrm{pH}$, water activity, Eh, preservatives competing microbiota, natural food) and the extrinsic parameters of the processing and storage (temperature, freezing, irradiation, dehydration, packaging, humidity) on staphylococcal survival, growth and enterotoxin are a very important goal. While staphylococci can be destroyed easily the enterotoxins can survive practically all the food processing steps. While extreme levels of the intrinsic variables can control the enterotoxin production, yet the environment of the most foods is conductive to the staphylococcal growth. Rapid food cooling, adequate refrigeration and immediately consumer, besides the efforts for appropriate food handler and processor education remains the key to the staphylococcal food poisoning prevention (Genigeorgis, 1989).

\section{Salmonella spp.}

It is estimated that E. coli and Salmonella enterica diverged some 100 million years ago. The majority of the differences between the two genera result from the acquisition of large tracts of the DNA termed loop, or genomic islands (Hart and Winstanley, 2001). Salmonella spp. is one of the most commonly reported causes of the food borne disease in UK and in USA and in many other countries around the world (Varma, 2005). Since Salmonella spp. may be found in the intestinal tracts of the man and animals, it is easy to understand how widespread the contamination of the meats and vegetables can occur, and how difficult it can be to control the infection.

Salmonella is the leading cause of human food borne infections in Latin America, and poultry meat is one of the main vehicles. The slaughtering process in these abattoirs is manual and rudimentary, and frequently the hygienic conditions are poor. In one study with these abattoirs (Fuzihara et al., 2000) reported that $41 \%$ percent of the samples harbored Salmonella spp., including $42 \%$ of carcasses, $23 \%$ of utensils and $71 \%$ of water, freezers and refrigerators. Berends 
et al. (1998) described the contamination of the pork with Salmonella spp. in the cutting plants and butcher's shops in The Netherlands and quantified the influence of several risk factors. They found that when the contaminated carcasses were being processed, the main risk factors regarding the cross contamination were inapt cleaning and disinfection, manipulation of contaminated materials as such and (re)contaminated surfaces. It was observed that in contrast to the situation in the cutting plants, the butcher's shops or kitchens of the restaurants became colonized up to $10 \%$ for several weeks or months with their own endemic 'house flora' of Salmonella spp., which were originally introduced via the purchased contaminated products of the animal origin.

Santos and Kupek (2000) described the epidemic profile of the outbreaks of the food infection caused by $S$. Enteritidis in the south Brazil. Mayonnaise was the food most frequently associated with the outbreaks, being the responsible vehicle in almost two thirds of the cases investigated. They found that the outbreaks most frequently occurred at home $(60 \%)$, but the largest number of the infections resulted from the industrial kitchens (78\%). Peresi et al., (1998) reported the outbreaks of salmonellosis in São Paulo, Brazil. They found that there were 906 ill persons, including 295 hospitalized patients. Phage type $4 \mathrm{~S}$. Enteritidis strains were isolated from $80 \%$ of the stool samples, from $100 \%$ of the food samples and from $41 \%$ of the eggs. Of the outbreaks, $95 \%$ were associated with the consumption of the food containing raw or undercooked eggs. Hofer and Reis (1994) reported the presence of Salmonella serovars involved in 25 food poisoning episodes which occurred in the Southeast and South of Brazil from 1982 to 1991. They showed that the most frequently detected serotype was $S$. typhimurium (52\%), and the food most frequently involved in the transmission of Salmonella was homemade mayonnaise. The need to set up a permanent program of education of handlers as well as of epidemiologic alert for the food poisoning is emphasized.

\section{Heterotrophic bacteria}

The isolation of microorganisms by the growth on various culture media generally represents the first basic step in more detailed investigations of the nature, source, and potential risk of the bacterial contamination of the food, water and the environment (Allen et al., 2004). Heterotrophic bacteria are the microorganisms that use organic nutrients for the growth and multiplication and are ubiquitous, present in the water, food, vegetation and air. Heterotrophic plate count bacteria represent those microorganisms isolated by a particular method that can be enumerated by counting the bacterial colonies produced on an agar-based medium under the defined incubation temperature and time (Allen et al., 2004). Heterotrophic plate count is well established as an important parameter for the assessment of water and food quality.

Food safety is an important part of the public health linking the health to agriculture and other food production sectors (Schlundt, 2002). For over a century, developments in the food production and new control philosophies have contributed to the food safety systems in most developed countries perceived by many to be efficient in the prevention of the food borne disease. Nevertheless, a number of problems still remain dominant, one of these being the high level of the food borne microbiological diseases which seem, for some pathogens, to have increased over the last decades.

\section{Factors involved in food-borne diseases}

Various factors contribute to the outbreaks of the food borne illness. The main ones are: i) inadequate food manipulation; ii) improper holding temperatures (failing to properly refrigerate food); iii) inadequate cooking; iv) contaminated equipment (failure to clean and disinfect kitchen or processing plant equipment) and v) poor personal hygiene. Other factors that may contribute to the food borne illness include: vi) preparing food a day or more before serving with improper holding and reheating; vii) cross contamination (from raw to cooked products) and viii) adding contaminated ingredients to the previously cooked food. After foods are contaminated, the main factor is letting them remain at a temperature that allows the growth of the potentially hazardous microorganisms or its toxin production in the food.

\section{Cross contamination and food handling}

Cross-contamination during food preparation has been identified as an important factor associated with the food-borne illness (Wanyenya et al., 2004). The food handlers play a major role in ensuring the food safety throughout the chain of the producing, processing, storage and preparation. 
Mishandling and disregard for the hygiene measures on their part may result in food contamination and its attendant consequences. Food borne illness affect millions of the people each year and an unknown but sizeable proportion of these illnesses could be prevented by the actions taken by the food handlers and consumers. Close cooperation at local, national and international levels with the epidemiologists and authorities responsible for the surveillance and prevention of the food-borne diseases is important and should not be forgotten. The best way to reduce these risks is to take steps to train the people involved in the food-handling (Gilling et al., 2001). The cleaning procedures for the food contact surfaces should be evaluated and special attention should be given to the utensils used during the processing, such as gloves, baskets, kitchen towels and hand tools (Souza et al., 2003). The U.S. Food and Drug Administration (FDA) recommends that the food shall be prepared with the least possible manual contact, with suitable utensils, and on the surfaces that prior to use have been cleaned, rinsed and sanitized to prevent cross-contamination (FDA, 1978).

Equipment and utensils have many opportunities to become contaminated and to contaminate. They are known to have become contaminated with the pathogens from the human reservoir, rodents and insects, sewage escaping from the faulty pipes and drains, unpotable water, condensation caused by the faulty ventilation, and contaminated food (FDA, 1978). Most of these problems could be controlled with the efforts on the part of the food handlers, whether in a processing plant, a restaurant, and others. The tremendous turnover of the food workers makes effective training difficult. The trained microbiologists and food technologists should set an example for the personal hygiene and food handling practices.

We are constantly subject to risks or hazards during our lifetimes. However, the foods could be safer today due to increased knowledge about the microbes and sanitation as well as increased regulations process. On the other hand, due to large-scale, high-speed food processing, alteration of the traditional processing methods resulting in less control of the microorganisms, proliferation of heat-and-eat convenience foods and nationwide distribution with increased potential for mishandling, there is concern that the outbreaks of the food borne illness can occur worldwide. The public health interventions to reduce the transmission of the food borne illness should focus on general hygienic measures in the street food trade, i.e. hand washing with the soap, adequate food-handling hygiene, and frequent renewal of the dishwater.

\section{Partitioning}

This practice occurs when a large unit is split up into several small units. To describe the transmission dynamics of a pathogen over a food pathway in quantitative microbiological risk assessment, several types of processes need to be modeled. Next to the microbial processes, such as the bacterial growth and inactivation, some food handling processes can be identified such as the partitioning and mixing of the food product. In contrast with most chemical hazardous compounds, the concentration of the food pathogens changes during the processing, storage, and meal preparation, making it difficult to estimate the number of the microorganisms or the concentration of their toxins at the moment of ingestion by the consumer (Devlieghere et al., 2004). These changes are attributed to the microbial proliferation, survival, and/or inactivation and must be considered when exposure to a microbial hazard is assessed. The number of microorganisms can also change as a result of physical removal, mixing of the food ingredients, partitioning of a food product, or cross-contamination (Nauta, 2002).

The health and spoilage hazards arising from the refrigerated and deep frozen foods may be due to the raw materials, e.g. pathogenic microorganisms which come from the infected living animals or contaminate raw foods during the handling process. The psychrotrophic organisms have particular significance as the pathogens or the spoilage organisms as they can multiply also during the refrigeration due to improper processing. Temperature abuse and incorrect time/temperature relations are main causes for the microorganisms being not destroyed at the expected rate or even getting a chance of multiplying. The proper handling after the refrigeration or frozen storage of the foods ("hygiene of thawing") deserves also particular attention - contamination, i.e. initial contamination of the raw products which are ready for the consumption without further processing (fruits, raw salads). Recontamination which follows a heat process is much more important and occurs before, during and after application of the cold. In those 
cases, again, one has to distinguish between the products which (a) are ready for the consumption without a process (bakery and confectionary goods, ice cream, drinking milk) and (b) have to pass a process which reduces the bacterial load before consuming the food (ready to eat dishes or other foods ready for reheating in the home). The sites of increased hygienic hazard are i) lack of partitioning "clean" and "unclean" areas and processes; ii) defects of sanitation and hygiene of personnel; iii) defects of packaging and iv) leakage during aseptic filling. The hazards are controlled through product and plant specific analysis of the process flow followed by the continuous monitoring the "Critical Control Points". As an example, a report is given on a study on random samples taken from 180,000 prepackaged deep frozen menus which had been produced for a mass meeting. The microbiological monitoring of the process revealed time/temperature relations as the critical control points of the primary importance. Particular problems arose from any stoppage at the production line. Reliable means to assure the food safety and protect consumer's health are the basis for the hazards analysis and critical control points (HACCP) concept based in plant control programs rather than sporadic microbiological monitoring of end products.

\section{Handling practices}

The handling practices in the food preparation areas, therefore, provide an opportunity for crosscontamination of the bacteria to ready-to-eat foods.

The microbiological analyses of the workers' hands were made for some microorganims, including the aerobic mesophilic plate counts, as well as the some food pathogens (Almeida et al., 1995), which revealed the possibilities of the cross-contamination of the roast beef by the workers' hands during the slicing operations. The workers' hands showed aerobic mesophilic plate counts of up to $10^{7} \mathrm{CFU} / \mathrm{hand}$ and the presence of S. aureus and Clostridium perfringens. It could be concluded that handling of these foods by such workers would be a risk in transmitting the pathogenic microorganisms to the foods and are apparent that would be necessary for these workers to take care of personal hygiene.

Unsanitary food handling is a major public health hazard. The effect of basic food hygiene knowledge on the hygienic practice identifies the specific areas for emphasis in the development and delivery of effective food safety risk communication messages to the consumers. Another aspect of some studies (Almeida et al., 1995; Sinell, 1989) showed that, in most cases, when the safety and hygienic practices were not respected, the food became a true microorganism culture medium under the tropical climatic conditions. In general, some results (Barro et al., 2002), showed the failure of the microbial quality of some food which is not preheated (milk product, fruit juice, vegetable, fruit) and in the case of food which is not reheated after a long time of exposition (dry meat and meat on sticks). The presence of Salmonella and Shigella species in some food represents a serious danger for the consumers. These aspects were observed with most street food vendors (Muleta and Ashenafi (2001). It probably makes the street food the source of most diseases caused by the bacteria and other microorganisms.

In a survey conducted by Barro et al. (2002) they found that the major part of the population of Ouagadougou, Burkina Faso, had their breakfast, lunch and dinner in the street food shops. Women play a major part $(75 \%)$ in street food sale. Vendors have only a slight knowledge of the food processing and of hygienic practices. There is a high proportion (about 50\%) of people among them. This dietary habit has some negative aspects on the consumers' health. The hygienic practices during the sales operations were not respected by all the categories of the vendors of the food products. Also, it was observed that the street food vendors sometimes sat close to the waste water drainage system and solid wastes. Sometimes, the food was not appropriately covered and it was manipulated by the consumers in the areas infested by the flies and others insects. The water used to wash the materials is of poor quality. Some authors showed similar results working with the manipulators (Souza et al., 2003), mold isolated from the foods (Souza et al., 2005) and sugarcane juice in Brazil (Oliveira et al., 2006).

A survey of the selling conditions and bacteriological examinations of the ice-cream was carried-out by Ravaonindrina et al. (1996). The authors reported that the sellers had the classic features of a street-vended food vendor: uneducated, having no professional training and mishandling foodstuffs. In 202 samples of the icecream collected, the contamination prevalence rate was of $95 \%+/-3.7 \%$. S. typhimurium was isolated 
from one sample and recommended that immediate and rigorous measures ought to be put into effect by the authorities to control this alarming situation.

Muleta and Ashenafi (2001) evaluated the bacteriological safety of the food items sold by the street vendors with regard to Salmonella and Shigella to assess the growth potential of some food borne pathogens in some street foods. The authors found that most of the street food samples had aerobic mesophilic counts $>10^{7} \mathrm{cfu} / \mathrm{g}$. Nine "kitfo" and one "egg sandwich" samples yielded Salmonella. Shigella was isolated from three "macaroni" samples. The Salmonella isolates were sensitive to all the 10 drugs tested but the Shigella isolates had multiple resistances against five drugs. In a challenge study, Salmonella typhimurium, Shigella flexneri and Staphylococcus aureus grew in the street-vended food samples to hazardous levels within eight to twelve hours. They concluded that the street foods were heavily contaminated with microorganisms and were potential sources of the food borne infections and suggested that health hazards from the street foods could be significantly minimized by the consumption within four hours of preparation.

Table 1 - Major etiological agents causing food-borne diseases related with food involved, symptoms, reservoir and references in Brazil and other countries.

\begin{tabular}{|c|c|c|c|c|c|}
\hline Agent & Disease & Food involved & Symptoms & Reservoir & Reference \\
\hline $\begin{array}{l}\text { Escherichia coli } \\
\text { pathotypes: } \\
\text { EHEC serotype } \\
\text { O157:H7 }\end{array}$ & $\begin{array}{l}\text { diarrhoeal illness } \\
\text { hemorrhagic } \\
\text { colitis, bloody } \\
\text { diarrhea , HUS* }\end{array}$ & $\begin{array}{l}\text { uncooked } \\
\text { minced meat } \\
\text { and raw milk }\end{array}$ & $\begin{array}{l}\text { abdominal } \\
\text { cramps, bloody } \\
\text { diarrhea }\end{array}$ & $\begin{array}{l}\text { typical } \\
\text { component of } \\
\text { the fecal } \\
\text { microbiota }\end{array}$ & $\begin{array}{l}\text { WHO, (2002); } \\
\text { Pickering et } \\
\text { al., (1994); } \\
\text { Sousa, (2005); } \\
\text { Lamps (2007) }\end{array}$ \\
\hline $\begin{array}{l}\text { Staphylococcus } \\
\text { spp. }\end{array}$ & $\begin{array}{l}\text { staphylococcal } \\
\text { food poisoning }\end{array}$ & $\begin{array}{l}\text { raw foods of } \\
\text { animal origin; } \\
\text { milk; cakes; }\end{array}$ & $\begin{array}{l}\text { vomiting, } \\
\text { diarrhea, } \\
\text { abdominal } \\
\text { cramps }\end{array}$ & $\begin{array}{l}\text { men and } \\
\text { animals }\end{array}$ & $\begin{array}{l}\text { Bergdoll, } \\
\text { (2000); Carmo } \\
\text { et al. (2004); }\end{array}$ \\
\hline Salmonella spp. & $\begin{array}{l}\text { food borne } \\
\text { infections }\end{array}$ & $\begin{array}{l}\text { pork, } \\
\text { mayonnaise, } \\
\text { raw and/or } \\
\text { undercooked } \\
\text { eggs. }\end{array}$ & $\begin{array}{l}\text { fever, diarrhea, } \\
\text { abdominal } \\
\text { cramps }\end{array}$ & $\begin{array}{l}\text { men and } \\
\text { animals }\end{array}$ & $\begin{array}{l}\text { Berends et al. } \\
(1998) ; \\
\text { Fuzihara et al., } \\
\text { (2000); Santos } \\
\text { and Kupek } \\
\text { (2000); Hofer } \\
\text { and Reis } \\
\text { (1994) }\end{array}$ \\
\hline
\end{tabular}

* hemolytic uremic syndrome

\section{CONCLUSION, GOALS AND PERSPECTIVES}

The microbiological criteria for the food products and meals serve to gauge the results obtained upon monitoring the samples from the manufacturing plants or catering units which strictly adhere to good manufacturing practices. After eliminating the hazardous practices, the aim of the monitoring should be to detect and, above all, immediately correct accidental failures in the processing or preparation steps. This continuous education process, practices and perspectives would contribute to the impact of good manipulation practices and guarantee the food safety and food quality to the consumer.

\section{RESUMO}

Doenças veiculadas por alimentos são um dos maiores problemas de Saúde Pública no mundo, sendo responsáveis por reduções no crescimento econômico global. A contaminação de alimentos com patógenos e sua persistência, crescimento, multiplicação e/ou produção de toxinas é de interesse da Saúde Pública. Estes problemas podem ser controlados com esforços e treinamento constante de manipuladores de alimentos. Em contraste com perigos químicos e 
físicos, a concentração de patógenos em alimentos é modificada durante etapas de processamento, acondicionamento e preparação, tornando difícil estimar e quantificar o número de microrganismos ou a concentração de suas toxinas no momento da ingestão do alimento. Esta revisão comenta sobre os principais microrganismos bacterianos relacionados à práticas de manipulação como Staphylococcus spp., Escherichia coli e Salmonella spp. ressaltando o consumo de alimentos em ruas, o desenvolvimento de doenças veiculadas por alimentos e enfatizando o impacto de boas práticas de manipulação na segurança e qualidade de alimentos.

\section{REFERENCES}

Allen, M. J.; Edberg, S. C. and Reasoner, D. J. (2004), Heterotrophic plate count bacteria-what is their significance in drinking water? Int. J. Food Microbiol., 92, 265-274.

Almeida, R. C.; Kuaye, A. Y.; Serrano, A. M. and Almeida, P. F. (1995), Evaluation and control of the microbiological quality of hands in foodhandlers. Rev. Saude Publica, 29, 290-294.

Barro, N.; Ouattara, C. A.; Nikiema, P. A.; Ouattara, A. S. and Traore, A. S. (2002), Microbial quality assessment of some street food widely consumed in Ouagadougou, Burkina Faso. Sante, 12, 369-374.

Berends, B. R.; Van Knapen, F.; Mossel, D. A.; Burt, A. S. and Snijders, J. M. (1998), Salmonella spp. on pork at cutting plants and at the retail level and the influence of particular risk factors. Int. J. Food Microbiol., 44, 207-217.

Bergdoll, M. S. (2000), Staphylococcus até onde sua importância em alimentos? Hig. Alim., 14, 32-40.

Blood, R. M.; Curtis, G. D. W. (1995), Media for "total" Enterobacteriaceae, coliforms and Escherichia coli. In.t J. Food Microbiol., 26, 93115.

Bryan, F. L. (1982), Diseases transmitted by foods. In-The United States Centers for Disease Control, classification and summary. $2^{\text {nd }}$ ed. Atlanta.

Carmo, L. S.; Cummings, C.; Linardi, V. R.; Dias, R. S.; Souza, J. M.; Sena, M. J.; Santos, D. A.; Shupp, J. W.; Pereira, R. K. and Jett, M. (2004), A case study of a massive staphylococcal food poisoning incident. Foodborne Pathog. Dis., 1, 241-246.

Devlieghere, F.; Francois, K.; Vereecken, K. M.; Geeraerd, A. H.; Van Impe, J. F. and Debevere, J. (2004), Effect of chemicals on the microbial evolution in foods. J. Food Prot., 67, 1977-1990.

Food and Drug Administration. Food Service Manual, (1978), U.S. Department of Health,
Education and Welfare, Public Health Service. DHEW Publ. No. (FDA); 78-2081, Washington, DC.

Forsythe S. J.; Hayes, P. R. (1988), Food Hygiene, Microbiology and HACCP. A Chapman and Hall Food Science Book. Aspen Publishers, Gaithersburg.

Fuzihara, T. O.; Fernandes, A. S. and Franco, B. D. (2000), Prevalence and dissemination of Salmonella serotypes along the slaughtering process in Brazilian small poultry slayghterhouses. J. Food Prot., 63, 1749-1753.

Genigeorgis, C. A. (1989), Present state of knowledge on staphylococcal intoxication. Int. J. Food Microbiol., 9, 327-360.

Gilling, S.; Taylor, E. A.; Kane, K.; Taylor, J. Z. (2001), Successful hazard analysis critical control point implementation in the United Kingdom: understanding the barriers through the use of a behavioral adherence model. J. Food Protect., 64, 710-715.

Hart, C. A.; Winstanley, C. (2001), What makes a pathogen? Microbiol. Today, 28, 4-6.

Hofer, E.; Reis, E. M. (1994). Salmonella serovars in food poisoning episodes recorded in Brazil from 1982 to 1991. Rev. Inst. Med. Trop. Sao Paulo, 36, 7-9.

Lamps, L. W. (2007), Infective disorders of the gastrointestinal tract. Histopathology, 50, 55-63.

Lukinmaa, S.; Nakari, U.; Eklund, M.; Siitonen, A. (2004), Application of molecular genetic methods in diagnostics and epidemiology of food-borne bacterial pathogens. APMIS, 12, 908-929.

Menard, L. P.; Dubreuil, J. D. (2002), Enteroaggregative Escherichia coli heat-stable enterotoxin 1 (EAST1): a new toxin with an old twist. Crit. Rev. Microbiol., 28, 43-60.

Mensah, P.; Yeboah-Manu, D.; Owusu-Darko, K.; Ablordey, A. (2002), Street foods in Accra, Ghana: how safe are they? Bull. World Health Org., 80, 546-554.

Muleta, D.; Ashenafi, M. (2001), Salmonella, Shigella and growth potential of other food-borne pathogens in Ethiopian street vended foods. East Afr. Med. J., 78, 576-580.

Nauta, M. J. (2002), Modelling bacterial growth in quantitative microbiological risk assessment: is it possible? Int. J. Food Microbiol., 73, 297-304.

Oliveira, A. C. G., Seixas, A. S. S.; Sousa, C. P.; Souza, C. W. O. (2006), Microbiological evaluation of sugarcane juice sold at street stands and juice handling conditions in Sao Carlos, Sao Paulo, Brazil. Cad. Saude Public., 22, 1111-1114.

Peresi, J. T.; Almeida, I. A.; Lima, S. I.; Marques, D. F.; Rodrigues, E. C.; Fernandes, S. A.; Gelli, D. S.; Irino, K. (1998), Food borne disease outbreaks caused by Salmonella enteritidis. Rev. Saude Publica, 32, 477-483. 
Pickering, L. K.; Obirg, T. G.; Stapleton, F. B. (1994), Hemolytic-uremic syndrome and enterohemorrhagic Escherichia coli. Pediatr. Infect. Dis. J., 13, 459-476.

Ravaonindrina, N.; Rasolomandimby, R.; Rajaomiarisoa, E.; Rakotoarisoa, R.; Andrianantara, L.; Rasolofonirina, N.; Roux, J.F. (1996), Street-vendor foods: quality of ice creams, sherbets and sorbets sold in the urban agglomeration of Antananarivo. Arch. Inst. Pasteur Madagascar, 63, 67-75.

Santos, S. M.; Kupek, E. (2000), Serial outbreaks of food-borne disease in Blumenau, Brazil, caused by Salmonella enteritidis. Braz. J. Infect. Dis., 4, 275278.

Schlundt, J. (2002), New directions in foodborne disease prevention. Int. J. Food Microbiol.; 78, 317.

Sinell, H. J. (1989), The hygiene of refrigerated and frozen foods. Zentralbl. Bakteriol. Mikrobiol. Hyg., 187, 533-545.

Sousa, C. P. (2003), Pathogenicity mechanisms of prokaryotic cells: an evolutionary view. Braz. J. Infect. Diseas. , 7, 23-31.

Sousa, C. P. (2005), The strategies of Escherichia coli pathotypes and health surveillance. Revisa, $\mathbf{1}$, 65-70.
Souza, E. L.; Silva, B. H. C.; Sousa, C. P. (2003), Manipuladores como causas potenciais de contaminação de alimento enteral. São Paulo. Infarma, 15, 71-73.

Souza, E. L.; Silva, C. A.; Sousa. C. P. (2005), Bacteriocins molecules of fundamental impact on the microbial ecology and potential food biopreservatives. Braz.. Arch. Biolog. Technol., 48, 559-566.

Souza, E. L.; Lima, E. O.; Sousa, C. P. (2005). Inhibitory action of some essential oils and phytochemicals on the growth of various moulds isolated from foods. Braz. Arch. Biolog. Technol., 48, 245-250.

Varma, J. K. (2005), Hospitalization and antimicrobial resistance in salmonella outbreaks, 1984-2002. Emerg. Infect. Dis., 11, 943-946.

W.H.O. (2002), Emerging foodborne diseases. Fact Sheet 124. Available at: www.who.int/inffs/en/fact124.html.

Wanyenya, I.; Muyanja, C.; Nasinyama, G. W. (2004), Kitchen practices used in handling broiler chickens and survival of Campylobacter spp. on cutting surfaces in Kampala, Uganda. J. Food Protect., 67, 1957-1960. 